\title{
Assessment of the Teaching Methods that Influence the Acquisition of Practical Skills
}

\author{
Audu, R. ${ }^{1,2}$, Yusri Bin Kamin ${ }^{2}$, Aede Hatib Bin Musta'amal ${ }^{2} \&$ Muhammad Sukri Bin Saud ${ }^{2}$ \\ ${ }^{1}$ Department of Industrial Technology Education, Federal University of Technology Minna, Nigeria \\ ${ }^{2}$ Department of Technical \& Engineering Education, Universiti of Teknologi Malaysia, Malaysia \\ Correspondence: Yusri Bin Kamin., Department of Technical \& Engineering Education, Universiti of Teknologi \\ Malaysia, Malaysia. Tel: 60-19-756-7679. E-mail: p-yusri@gmail.com
}

\author{
Received: April 12, 2014 Accepted: September 16, 2014 Online Published: October 30, 2014 \\ doi:10.5539/ass.v10n21p35 URL: http://dx.doi.org/10.5539/ass.v10n21p35
}

\begin{abstract}
This study is designed to identify the teaching methods that influence the acquisition of practical skills of mechanical engineering trades students at technical college level using regression analysis. Descriptive survey research design was utilized in carrying out the study. Ninety nine (99) mechanical engineering trades' teachers and fourty six (46) administrators in the technical colleges in north central states of Nigeria responded to a structured questionnaire which addressed the research question. Cronbach Alpha coefficient was used in determining the reliability of the instrument. The reliability co-efficient of the instrument used for data collection stood at 0.78 . It was recommended that mechanical engineering trades teachers and administrators in the schools be encouraged to use different instructional methods, especially the methods identified in the study as the most significant determinants of the teaching methods that influence the acquisition of practical, so that the students can acquire the skills for gainful employment in the labor market or be able to establish on their own and become self-reliant.
\end{abstract}

Keywords: teaching methods, practical skills, regression analysis, mechanical engineering trades

\section{Introduction}

Technical Vocational Education (TVE) could be termed as that aspect of education which provides the recipients with the basic knowledge and practical skills necessary for entry into the world of work as employees or as self-employed. According to Maclean and Wilson (2009) TVE is concerned with the acquisition of skills and knowledge for employment and sustainable livelihood. Abassah (2011) stated that TVE involves training in the process of relating both science and technical education to practical problems right from primary to higher level of education; this is because it aims at developing practical skills as well as the creative and innovative abilities and enables decision making skills and problem solving abilities.

However, technical colleges in Nigeria are regarded as the principal vocational institutions. They give full vocational training intended to prepare students for entry into various trade areas. The technical colleges are established to produce craftsmen at the craft (secondary) level and master craftsmen at the advance craft (postsecondary) level. According to International Qualifications Assessment Service (IGAS, 2011) the programs of technical colleges are classified into related trades, which includes mechanical engineering trades, electrical/electronic trades, construction trades, miscellaneous trades and business trades. Therefore, the ultimate goal of training Mechanical Engineering Trades (METs) students at technical college level is for the acquisition of knowledge, attitude and marketable skills for sustainable development. The training of the students is based on the production of skilful individuals who are proficient in production of goods and services that are not only relevant to themselves but to the society (Udofia, et al., 2012). All technical courses, irrespective of their levels and objectives must be structured and made to stress practical activities. Johannsen (2012) stated that practical skills consists of the knowledge of methods, processes, procedures, and techniques for conducting a specialized task and the ability to operate tools and equipment related to that task. The process of learning will be more effective when the students are being exposed to the actual working condition by practically applying their knowledge and also the skills that they had learned. Akuezuilo (2007) posited that the basic science and technology curriculum, including vocational education, is very practical in nature and should be taught through methods that make best use of the active participation of the learners. 
Kennedy (2011) reported that the trend in the methods of teaching TVE programs in Nigerian technical and vocational schools is too theoretical with less emphasis on the teaching of practical skills. He therefore, stated that teachers use lecture method in most cases in all aspect of their teaching which also involve those topics that needed other teaching methods. While the result of the study shows how important the teaching approaches are towards the development of practical skills in METs students, Bello, et al., (2007) conducted a study and postulated that, the hope and future of any nation depends on the future of its youths which require high resource investment for both long and short term benefits of the country. NOUN (2008) stated that a good teaching method should consider the ability of the learners in their various groups such as the average, below average and those above average. It should also be able to help the learner to make discoveries and also contribute to the learning activities.

Dar-Chin, Shao-Tsu and Ming-Hua (2006) postulated that, the world is a global village full of technological and economy based knowledge for people to prosper. Changes are being witnessed in society and industry, teaching and learning approaches, social values diversification etcetera, students can no longer be passive learners and take only what they could get from school alone. Peter, et al., (2010) further affirms the result of their study and stated that, students must adapt to changes in line with their levels of thinking on handling machineries and equipment so as to commensurate with the industrial needs. In order to achieve the national goals as stipulated by the Federal Republic of Nigeria (FRN) in the National Policy on Education (FRN, 2004 ) teachers should employ appropriate teaching methods in the teaching of TVE. Therefore, TVE teachers' needs to use the right method of instruction in order to enable the students acquire practical skills for them to be employable at the end of the completion of their program. It is on this premise that the study is design to identify the teaching methods that has significant influence on the acquisition of practical skills of METs students at technical college level in north central states of Nigeria.

\section{Objective of the Study}

The main aim of the study is to identify the teaching methods that influence the acquisition of practical skills of METs students at technical college level in Nigeria. Specifically, regression analysis was utilized to analyze the quantitative data collected from the respondents that participated in the research. The teaching methods that were considered in the study includes: demonstration, lecture, discussion, problem based learning, work based learning, project based learning, computer based instruction, simulation, field trip, context based learning, student centered and tutorials and seminar.

\section{Research Question}

The research question that guided the conduct of the research was answered and tested respectively. The research question reads; (What are the teaching methods that influence the acquisition of practical of mechanical engineering trades students skills?)

\section{Methodology}

The research methodology describes the procedures involved in carrying out the study which are discussed under relevant sub-headings below:

\subsection{Research Design}

Descriptive survey research design was utilized for data collection in the technical colleges in north central states of Nigeria. According to Osuala (1982) surveys are oriented toward the determination of status of a given phenomenon; they focus on people and their beliefs and opinions, attitudes and behavior. Therefore, questionnaire was used to determine the opinion and responses of METs teachers and the technical college administrators on the teaching methods that influence the acquisition of practical skills of METs students in the technical colleges in north central states of Nigeria.

\subsection{Sample and Sampling Technique}

A simple random sampling technique was used to select 17 out 28 technical colleges offering METs in north central states of Nigeria. The simple random sampling technique is a type of sampling method in which every element from the list of the population has equal probability of being selected (Ahmed, 2009). A Sample of 99 METs teachers and 46 technical college administrators were selected using purposive sampling technique from the 17 technical colleges that were utilized as sample for the study, making a total 145 respondents for the study. Purposive sampling is the type of sampling in which subjects are chosen to be part of the sample with a specific purpose in mind (Mathews and Ross, 2010). Institutions owned and controlled by the Federal and State Government of Nigeria based on their similar and harmonised characteristics in admission, curriculum and graduation requirements were involved in the selection of respondents for this research. 


\subsection{Instrumentation}

A structured questionnaire developed by the researcher on a five (5) point rating scale was the instrument used for data collection in this study, the instrument comprised of significant approaches considered determinants of the teaching methods that influence the acquisition of practical skills of mechanical engineering trades students. To determine the validity of the instrument, the items were critically examined by three experts in TVE for face and content validity. Cronbach Alpha coefficient was used in determining the reliability of the instrument. Cronbach's Alpha coefficient was used to ascertain the extent of homogeneity of the items in the questionnaire. Cronbach's Alpha is generally the most appropriate type of reliability for quantitative instrument (questionnaires) in which there is a range of possible answers for each item (McMillan \& Schumacher, 2006, p. 186). The reliability co-efficient stood at 0.78 ; which was considered high enough for the use of the instrument.

\section{Results}

The data collected for the study was analyzed based on the research question and were presented in the following tables below:

\subsection{Research Question: What Are the Teaching Methods that Influence the Acquisition of Practical of Mechanical Engineering Trades Students Skills?}

Table 1. Regression Analysis of METs teachers results on the teaching methods that influence the acquisition of practical skills of METs students

\begin{tabular}{|c|c|c|c|c|c|c|c|c|}
\hline \multirow[b]{2}{*}{ Item } & \multirow{2}{*}{$\begin{array}{l}\text { Significant Determinant of } \\
\text { Teaching Methods that Influence } \\
\text { the Acquisition of Practical Skills }\end{array}$} & \multicolumn{2}{|c|}{ U.C } & S.C & \multirow[b]{2}{*}{$\mathrm{t}$} & \multirow{2}{*}{ Sig. } & \multicolumn{2}{|c|}{$\begin{array}{l}95.0 \% \text { Confidence } \\
\text { Interval for B }\end{array}$} \\
\hline & & B & $\begin{array}{l}\text { Std. } \\
\text { Error }\end{array}$ & Bet & & & $\begin{array}{l}\text { Lower } \\
\text { Bound }\end{array}$ & $\begin{array}{l}\text { Upper } \\
\text { Bound }\end{array}$ \\
\hline 1(a) & Demonstration & 1.334 & .026 & .982 & 51.511 & .000 & 1.283 & 1.386 \\
\hline $2(a)$ & Demonstration & .728 & .077 & .536 & 9.513 & .000 & .577 & .880 \\
\hline (b) & Work based learning & .643 & .078 & .462 & 8.197 & .000 & .488 & .799 \\
\hline $3(\mathrm{a})$ & Demonstration & .535 & .078 & .393 & 6.869 & .000 & .380 & .689 \\
\hline (b) & Work based learning & .495 & .076 & .355 & 6.550 & .000 & .345 & .645 \\
\hline (c) & Simulation & .557 & .108 & .256 & 5.156 & .000 & .343 & .771 \\
\hline 4(a) & Demonstration & .425 & .078 & .313 & 5.463 & .000 & .271 & .580 \\
\hline (b) & Work based learning & .360 & .079 & .259 & 4.583 & .000 & .204 & .516 \\
\hline (c) & Simulation & .429 & .106 & .197 & 4.041 & .000 & .218 & .639 \\
\hline (d) & Fieldtrip & .351 & .090 & .238 & 3.891 & .000 & .172 & .531 \\
\hline $5(a)$ & Demonstration & .362 & .078 & .267 & 4.650 & .000 & .208 & .517 \\
\hline (b) & Work based learning & .287 & .080 & .206 & 3.609 & .000 & .129 & .445 \\
\hline (c) & Simulation & .335 & .107 & .154 & 3.138 & .002 & .123 & .547 \\
\hline (d) & Fieldtrip & .316 & .088 & .214 & 3.609 & .000 & .142 & .491 \\
\hline (e) & Context based learning & .366 & .124 & .167 & 2.948 & .004 & .119 & .612 \\
\hline $6(a)$ & Demonstration & .329 & .078 & .242 & 4.244 & .000 & .175 & .483 \\
\hline (b) & Work based learning & .232 & .081 & .167 & 2.849 & .005 & .070 & .394 \\
\hline (c) & Simulation & .294 & .106 & .135 & 2.766 & .007 & .083 & .504 \\
\hline (d) & Fieldtrip & .313 & .086 & .212 & 3.646 & .000 & .142 & .483 \\
\hline (e) & Context based learning & .299 & .125 & .136 & 2.395 & .019 & .051 & .547 \\
\hline (f) & Discussion & .274 & .120 & .117 & 2.280 & .025 & .035 & .513 \\
\hline $7(\mathrm{a})$ & Demonstration & .302 & .078 & .222 & 3.892 & .000 & .148 & .456 \\
\hline (b) & Work based learning & .158 & .088 & .114 & 1.799 & .075 & -.016 & .333 \\
\hline (c) & Simulation & .270 & .105 & .124 & 2.566 & .012 & .061 & .478 \\
\hline (d) & Fieldtrip & .279 & .086 & .188 & 3.236 & .002 & .108 & .449 \\
\hline (e) & Context based learning & .253 & .125 & .115 & 2.023 & .046 & .005 & .500 \\
\hline (f) & Discussion & .293 & .119 & .125 & 2.471 & .015 & .058 & .529 \\
\hline (g) & Problem based learning & .169 & .083 & .121 & 2.034 & .045 & .004 & .334 \\
\hline
\end{tabular}

Table 1 presents the result of Linear Regression Analysis using the 'Stepwise Criteria', though a significant regression model emerged with $\mathrm{F}_{7,98}=2653.426, \mathrm{p}<0.05, \mathrm{R}^{2}=.987$, seven (7) Predictor Variables (demonstration, work based learning, simulation, fieldtrip, context based learning, discussion and problem based learning) with $\mathrm{B}=.222, .114, .124, .188, .115, .125$ and .121 respectively, $\mathrm{p}<0.05$ are significant determinants 
of the teaching methods that influence the acquisition of practical skills of METs students at technical college level. Other determinants such as the use of tutorials and seminar method, the use of project based learning, the use of student centred method; the use of lecture method and the use of computer based instruction have less significant contribution towards influencing the acquisition of practical skills of METs students at technical college level in north central states of Nigeria. Table 2 below shows a summary of the seven (7) most significant determinants of teaching methods that influence the acquisition of practical skills of METs students at technical college level in Nigeria based on METs teachers responses.

Table 2. Summary of METs teachers results on the most significant determinant of teaching methods that influence the acquisition of practical skills of METs students

\begin{tabular}{|c|c|c|c|c|c|}
\hline $\begin{array}{l}\text { Item } \\
\text { No }\end{array}$ & $\begin{array}{l}\text { Most Significant Determinant of Teaching Methods that } \\
\text { Influence the Acquisition of Practical Skills }\end{array}$ & $\mathrm{R}$ & $\mathrm{R}^{2}$ & $\begin{array}{l}\text { Adjusted } \\
\mathrm{R}^{2}\end{array}$ & $\begin{array}{l}\text { Std. Error of the } \\
\text { Estimate }\end{array}$ \\
\hline $\mathrm{a}$ & Demonstration & $.982^{\mathrm{a}}$ & .964 & .964 & .93435 \\
\hline$b$ & Work based learning & $.989^{\mathrm{c}}$ & .979 & .979 & .72184 \\
\hline $\mathrm{c}$ & Simulation & $.992^{\mathrm{d}}$ & .984 & .983 & .64211 \\
\hline $\mathrm{d}$ & Fieldtrip & $.993^{\mathrm{e}}$ & .986 & .985 & .59947 \\
\hline e & Context based learning & $.993^{\mathrm{f}}$ & .987 & .986 & .57659 \\
\hline $\mathrm{f}$ & Discussion & $.994^{\mathrm{g}}$ & .988 & .987 & .56413 \\
\hline $\mathrm{g}$ & Problem based learning & $.994^{\mathrm{h}}$ & .988 & .987 & .55485 \\
\hline
\end{tabular}

The highest value of Adjusted $\mathrm{R}^{2}$ of .987 in Table 2 indicates that the model account for $98.7 \%$ variance in the teaching methods that influences the acquisition of practical skills of METs students at technical college level in Nigeria. This further reveals that these seven (7) items are most significant determinants of teaching methods that influence the acquisition of practical skills of METs students at technical college level in Nigeria based on METs teachers' responses.

Table 3. Regression analysis of administrators results on the teaching methods that influence the acquisition of practical skills of METs students

\begin{tabular}{|c|c|c|c|c|c|c|c|c|}
\hline \multirow[t]{2}{*}{ Item } & \multirow{2}{*}{$\begin{array}{l}\text { Significant Determinant of } \\
\text { Teaching Methods that Influence } \\
\text { the Acquisition of Practical Skills }\end{array}$} & \multicolumn{2}{|c|}{ U.C } & \multicolumn{2}{|l|}{ S.C } & \multirow{2}{*}{ Sig. } & \multicolumn{2}{|c|}{$\begin{array}{l}95.0 \% \text { Confidence } \\
\text { Interval for B }\end{array}$} \\
\hline & & B & $\begin{array}{l}\text { Std. } \\
\text { Error }\end{array}$ & Beta & $\mathrm{t}$ & & $\begin{array}{l}\text { Lower } \\
\text { Bound }\end{array}$ & $\begin{array}{l}\text { Upper } \\
\text { Bound }\end{array}$ \\
\hline $1(\mathrm{a})$ & Fieldtrip & 1.402 & .033 & .988 & 42.721 & .000 & 1.336 & 1.468 \\
\hline $2(a)$ & Fieldtrip & .993 & .095 & .700 & 10.495 & .000 & .802 & 1.184 \\
\hline (b) & Discussion & .674 & .149 & .301 & 4.521 & .000 & .374 & .975 \\
\hline $3(a)$ & Fieldtrip & .791 & .113 & .557 & 6.982 & .000 & .562 & 1.019 \\
\hline (b) & Discussion & .539 & .147 & .241 & 3.682 & .001 & .244 & .835 \\
\hline (c) & Tutorials and seminar & .496 & .175 & .207 & 2.829 & .007 & .143 & .850 \\
\hline 4(a) & Fieldtrip & .602 & .132 & .424 & 4.551 & .000 & .335 & .869 \\
\hline (b) & Discussion & .446 & .144 & .199 & 3.097 & .003 & .155 & .736 \\
\hline (c) & Tutorials and seminar & .444 & .168 & .185 & 2.650 & .011 & .106 & .782 \\
\hline (d) & Demonstration & .277 & .113 & .199 & 2.442 & .019 & .048 & .506 \\
\hline $5(a)$ & Fieldtrip & .414 & .145 & .292 & 2.866 & .007 & .122 & .706 \\
\hline (b) & Discussion & .285 & .149 & .127 & 1.906 & .064 & .017 & .586 \\
\hline (c) & Tutorials and seminar & .346 & .162 & .144 & 2.133 & .039 & .018 & .673 \\
\hline (d) & Demonstration & .296 & .107 & .213 & 2.767 & .008 & .080 & .512 \\
\hline (e) & Simulation & .393 & .154 & .232 & 2.548 & .015 & .082 & .705 \\
\hline $6(a)$ & Fieldtrip & .464 & .140 & .327 & 3.318 & .002 & .181 & .746 \\
\hline (b) & Discussion & .332 & .144 & .148 & 2.303 & .027 & .041 & .623 \\
\hline (c) & Tutorials and seminar & .391 & .156 & 163 & 2.503 & .016 & .075 & .706 \\
\hline (d) & Demonstration & .306 & .102 & .220 & 2.998 & .005 & .100 & .513 \\
\hline (e) & Simulation & .501 & .155 & .296 & 3.233 & .002 & .188 & .814 \\
\hline (f) & Context based learning & -.349 & .156 & -.148 & -2.235 & .031 & -.664 & -.033 \\
\hline
\end{tabular}


Table 3 presents the result of Linear Regression Analysis using the 'Stepwise Criteria', though a significant regression model emerged with $\mathrm{F}_{6,45}=1825.095, \mathrm{p}<0.05, \mathrm{R}^{2}=.989$, six (6) Predictor Variables (fieldtrip, discussion method, tutorials and seminar method, demonstration method, simulation and context based learning) with $\mathrm{B}=.327, .148, .163, .220, .296$ and -.148 respectively, $\mathrm{p}<0.05$ are significant determinants of the teaching methods that influence the acquisition of practical skills of METs students at technical college level. Other determinants such the use of work based learning, the use of problem solving approach, the use of project based learning, the use of student centred, the use of lecture and the use of computer based instruction have less significant contribution towards influencing the acquisition of practical skills of METs students at technical college level in north central states of Nigeria. Table 4 below shows a summary of the six (6) most significant determinants of teaching methods that influence the acquisition of practical skills of METs students at technical college level in Nigeria based on administrators responses.

Table 4. Summary of administrators results on the most significant determinant of teaching methods that influence the acquisition of practical skills of METs students

\begin{tabular}{llcccc}
\hline Item & $\begin{array}{l}\text { Most Significant Determinant of Teaching Methods that } \\
\text { Influence the Acquisition of Practical Skills }\end{array}$ & $\mathrm{R}$ & $\mathrm{R}^{2}$ & $\begin{array}{c}\text { Adjusted } \\
\mathrm{R}^{2}\end{array}$ & $\begin{array}{c}\text { Std. Error of the } \\
\text { Estimate }\end{array}$ \\
\hline $\mathrm{a}$ & Fieldtrip & $.988^{\mathrm{a}}$ & .976 & .975 & .76764 \\
$\mathrm{~b}$ & Discussion & $.992^{\mathrm{c}}$ & .984 & .983 & .64150 \\
$\mathrm{c}$ & Tutorials and seminar & $.993^{\mathrm{d}}$ & .986 & .985 & .59583 \\
$\mathrm{~d}$ & Demonstration & $.994 \mathrm{e}$ & .988 & .997 & .56416 \\
$\mathrm{e}$ & Simulation & $.995^{\mathrm{f}}$ & .990 & .988 & .53054 \\
$\mathrm{f}$ & Context based learning & $.995^{\mathrm{g}}$ & .991 & .989 & .50643 \\
\hline
\end{tabular}

The highest value of Adjusted $\mathrm{R}^{2}$ of .997 in Table 4 indicates that the model account for $99.7 \%$ variance in the teaching methods that influences the acquisition of practical skills of METs students at technical college level in Nigeria. This further reveals that these six (6) items are most significant determinants of teaching methods that influence the acquisition of practical skills of METs students at technical college level in north central states of Nigeria based on the school administrators' responses.

\section{Discussion}

Practical skills are the basic skills and rudiments that students are supposed to possess in their areas of specialization based on the designed modules in the curricula. Dar-Chin, Shao-Tsu and Ming-Hua (2006) postulated that, the world is a global village full of technological and economy based knowledge for people to prosper. Changes are being witnessed in society and industry, teaching and learning approaches, social values diversification etcetera, students can no longer be passive learners and take only what they could get from school alone. However, the findings of the study revealed that demonstration, work based learning, simulation, fieldtrip, context based learning, discussion, problem based learning, tutorials and seminar methods of teaching are the most significant predictor of practical skills of METs students based on the respondents opinion.

In order for the teachers to effectively teach the students to acquire the needed skills in their trade courses, they need to concentrate on these teaching methods highlighted. NOUN (2008) stated that a good teaching method should consider the ability of the learners in their various groups such as the average, below average and those above average. It should also be able to help the learner to make discoveries and also contribute to the learning activities. While the result of the study shows how important the teaching approaches are towards the development of practical skills in METs students, Bello, et al., (2007) conducted a study and postulated that, the hope and future of any nation depends on the future of its youths which require high resource investment for both long and short term benefits of the country. In a situation whereby the youths are properly trained and equipped with the needed practical skills, a lot of developments are realized through economic stability, empowerment of families and communities, and also focusing towards sustainable developments. Many countries have realized the significance of developing the youths on sound TVE through appropriate teaching methods in order to realize their educational objectives.

As the world is witnessing technological changes in all aspect of the field of technology, there is the need for METs students to acquire the requisite practical skills to be able to meet-up with the challenges of technological advancement being witnessed in the $21^{\text {st }}$ century. Peter, et al., (2010) affirms the result of their study and stated that, students must adapt to changes in line with their levels of thinking on handling machineries and equipment 
so as to commensurate with the industrial needs. This could only be achieved through the right teaching methods in order to equip the students with higher order thinking skills for them to be easily adaptable and flexible in their work. The use of the most appropriate teaching method is the only options left in the current globalize economy.

\section{Conclusion}

The acquisition of practical skills in TVE especially mechanical engineering trades is a major factor in the design of TVE programs. TVE is knowledge, skill and technology driven. It empowers students with skills and job creation potentials leading to poverty reduction. The acquisition of practical skills empowers the students with competence to practice, create, develop and establish self in the work place. Skills acquisition by students can only be achieved where the training institutions have competent and experienced teachers that adopt effective and efficient instructional methods. Therefore, it is recommended that METs teachers and administrators in the schools should be encouraged to use different instructional methods, especially the methods identified in the study as the most significant determinants of the teaching methods that influence the acquisition of practical, so that the students can acquire the skills for gainful employment in the labor market or be able to establish on their own and become self-reliant.

\section{References}

Abassah, M. (2011). Technical College Teachers in Nigeria: Issues, Problems and Challenges. Mediterranean Journal of Social Sciences, 2(7), 57-62.

Ahmed, S. (2009). Methods in Sample Surveys Simple Random Sampling Systematic Sampling Lecture 2. Retrieved from http://ocw.jhsph.edu/.../statmethodsforsamplesurveys/

Akuezuilo, E. O. (2007). The New 9-Year Basic Science and Technology Curriculum and Challenges of its Implementation. Journal of Curriculum and Instruction, 6(2), 1-6.

Bello, M. I., Danjuma, I. M., \& Adamu, A. Y. (2007). A Survey of Vocational Training Needs of 15-25 Years old Out-of-School Youths in Bauchi Metropolis. Journal of Career and Technical Education, 23(1), 55-71.

Dar-Chin, R., Shao-Tsu, C., Yi-Ping, L., \& Ming-Hua, C. (2006). Development and Teaching Approaches of Technical and Vocational Education Curricula. A Paper Presented at the 9th International Conference on Engineering Education (ICEE). July 23 - 28, 2006, 17-22.

Federal Republic of Nigeria. (2004). National Policy on Education. Lagos, Nigeria. Education Research and Development Council Press.

International Qualifications Assessment Service (IQAS). (2011). International Education Guide for the Assessment of Education from the Federal Republic of Nigeria. Edmonton, Alberta, Canada. Government of Alberta.

Johannsen, M. (2012). Three Key Skills Needed Inside Organizations. California: Legacee.

Kennedy, O. O. (2011). Re-appraising the Work Skill Requirements for Building Technology Education in Senior Secondary School for Optimum Performance in Nigeria. European Journal of Applied Sciences, 3(2), 46-52.

Maclean, R., \& Wilson, D. (Eds.). (2009). International Handbook of Education for the Changing World of Work: Bridging Academic and Vocational Learning. Dordrecht: Springer Science and Business Media. http://dx.doi.org/10.1007/978-1-4020-5281-1

Mathews, B., \& Ross, L. (Eds.). (2010). Research Methods: A Practical Guide for the Social Sciences. Italy: Rotolito, Lombarda.

McMillan, J. H., \& Schumacher, S. (2006). Research in education: Evidence-Based Inquiry (6th ed.). New York: Pearson Education, Inc.

National Open University of Nigeria (NOUN). (2008). Business Methods. Abuja: National Open University of Nigeria.

Osuala, E. C. (1982) Introduction to Research Methodology. Onitsha; African FEP Publishers Ltd.

Peter, O. I., Abiodun, A. P., \& Jonathan, O. O. (2010). Effect of Constructivism Instructional Approach on Teaching Practical Skills for Mechanical Related Trade Students in Western Nigeria Technical Colleges. International NGO Journal, 5(3), 59-64.

Udofia, A. E, Ekpo, A. B., Nsa, E. O., \& Akpan, E. O. (2012). Instructional Variables and Students’ Acquisition 
of Employable Skills in Vocational Education in Nigerian Technical Colleges. Scholarly Journal of Education. 1(2), 13-19.

\section{Copyrights}

Copyright for this article is retained by the author(s), with first publication rights granted to the journal.

This is an open-access article distributed under the terms and conditions of the Creative Commons Attribution license (http://creativecommons.org/licenses/by/3.0/). 